\section{French government concedes defeat to researchers}

Declan Butler, Paris

Scientists gathered outside the Sorbonne last week, not to demonstrate, but to picnic and toast with champagne a victory in their three-month conflict with the government.

The Save Research movement, which had led a series of protests (see Nature 428,$241 ; 2004$ ), called them off on 7 April after the government caved in to the researchers' demands.

The move came after French president Jacques Chirac's statement on 1 April, when he disowned the research policies of his previous government and declared the scientists' protests "justified". François Fillon, minister for education, higher education and research, and François d'Aubert, junior minister for research, who were appointed in a government reshuffle on 31 March,

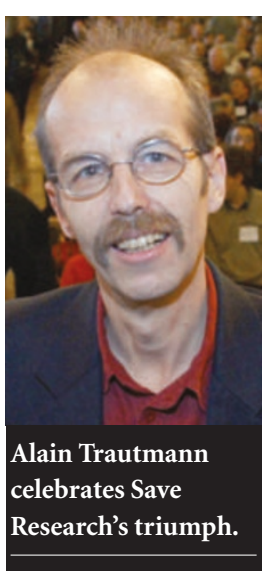
moved quickly to put Chirac's words into action. Following negotiations last week with representatives of the scientific community, Fillon and d'Aubert announced a series of emergency measures for research,

including the scientists' key demand of 550 new full-time research posts for young scientists. The government also agreed to a further 1,050 university posts -300 immediately and 750 in January 2005.

Fillon described the move as "an exceptional and immediate effort in favour of science jobs", and a means "to take the high ground" in defusing the situation. Finding a way out of the current crisis was imperative, he added, if progress is to be made on a planned reform and funding plan for French research that is expected to go before parliament by the end of the year. He also committed to the protesters' demands that the scientific community be brought on board in drafting the reforms.

"It's a great day for French science," said a jubilant Alain Trautmann, leader of Save Research. "We got exactly what we demanded."

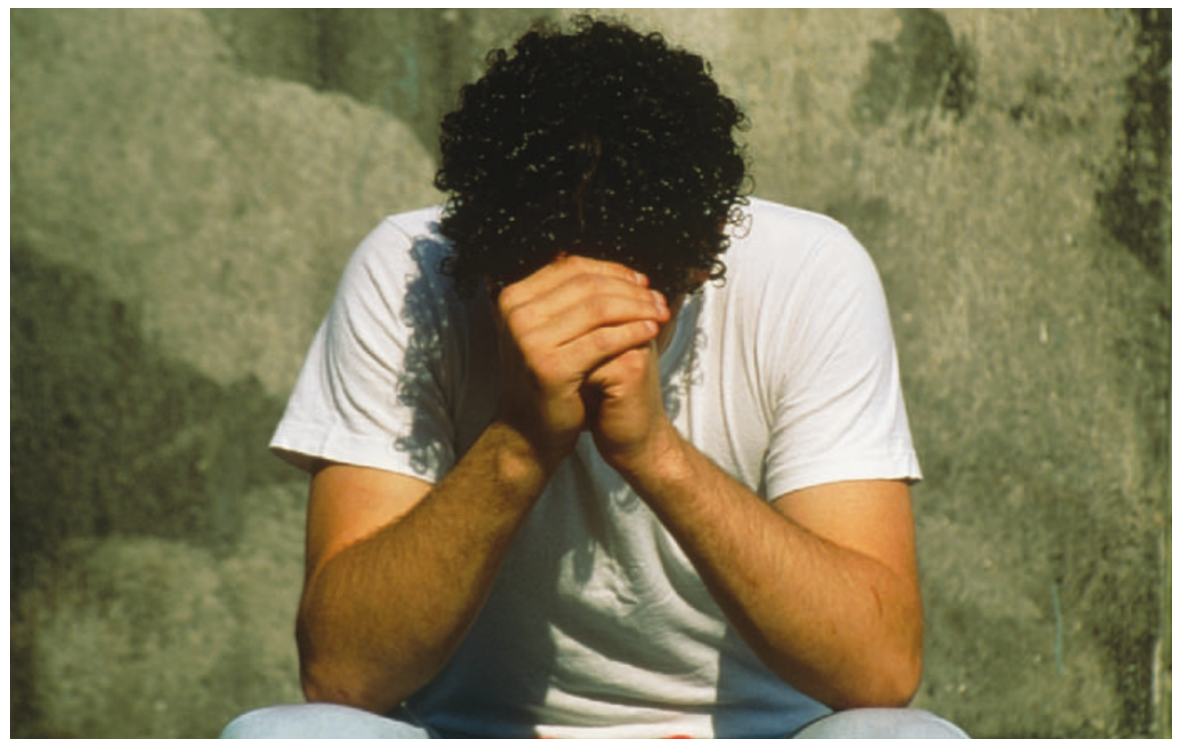

Depressed youngsters may get more benefit from behavioural therapy than from antidepressants.

\title{
Trial analysis questions use of antidepressants in children
}

Erika Check, Washington

Children taking antidepressants are unlikely to reap much benefit, according to researchers in Australia. They say instead that data from clinical trials, including some whose results helped win approval for the drugs, suggest that the treatment offers few advantages.

In a review published in the British Medical Journal on 10 April, child psychiatrist Jon Jureidini of the University of Adelaide, Australia, and his colleagues reanalysed the data from five trials of popular antidepressants, known as selective serotonin reuptake inhibitors, or SSRIs (J. N. Jureidini et al. Br. Med. J. 328, 879-883;2004).

"We found that a superficial look at the papers gives you one impression, but a deeper look gives a different impression," Jureidini says. "Very little benefit and the possibility of significant risks should equate to a good deal more caution in the use of the drugs."

The review appears as regulators and patient advocates around the world are taking a closer look at the drugs' safety and efficacy in children. British officials have cautioned doctors not to prescribe them to young people, and US regulators have strengthened warnings about the drugs' potential to increase the risk of suicide.

Jureidini's group looked at five published trials of paroxetine, fluoxetine and sertraline in children. These drugs are sold as Paxil, Prozac and Zoloft, respectively, in the United States, and as Seroxat, Prozac and Lustral in Britain, and were prescribed more than 6 million times to US children in 2002 alone.

Two of the studies - one of fluoxetine, one of sertraline - had reported that the drugs helped children to overcome depression. But when Jureidini and his colleagues grouped the data on the five trials together, they found that the drugs as a class had only a marginal effect - the equivalent of an improvement of 3-4 points on a depression scale that ranges from 17 to 113 .

They also found that children in the placebo groups of the studies improved almost as much as children in the treatment groups. And significantly more children taking paroxetine and sertraline dropped out of the trials because of adverse events than those in the placebo groups, they report.

Jureidini and his colleagues also contend that the drugs' popularity is diverting patients from treatments that could help them more, such as cognitive behavioural therapy, which teaches patients about their thinking patterns and their reactions to difficult situations.

Authors of the published studies say that grouping the data from positive and negative studies together dilutes the positive findings of individual studies.

"If you pool all these studies and average them out, you get less significance," concedes Graham Emslie, a psychiatrist at the University of Texas Southwestern Medical Center at Dallas, who led two studies of fluoxetine that were scrutinized in Jureidini's review. But Emslie says that the antidepressants still work better than any other treatment studied. "It concerns me that they are suggesting that people put more faith into unproven treatments than into treatments that have actually been studied," he adds.

Emslie also says that the only treatment that might work better than antidepressants is cognitive behavioural therapy, and that he is leading an ongoing study, due to be completed in about three months, that compares the benefits of this with those of medication. 